\title{
Kernos
}

Revue internationale et pluridisciplinaire de religion grecque antique

$11 \mid 1998$

Varia

\section{Artemis of Ephesos: An Avant Garde Goddess}

\section{Frederick E. Brenk}

URL: http://journals.openedition.org/kernos/1224

DOI: $10.4000 /$ kernos. 1224

ISSN: 2034-7871

\section{Publisher}

Centre international d'étude de la religion grecque antique

Printed version

Date of publication: 1 January 1998

ISSN: 0776-3824

\section{Electronic reference}

Frederick E. Brenk, "Artemis of Ephesos: An Avant Garde Goddess », Kernos [Online], 11 | 1998, Online since 21 April 2011, connection on 19 April 2019. URL : http://journals.openedition.org/kernos/1224 ; DOI : 10.4000/kernos. 1224 


\section{Artemis of Ephesos}

\section{An Avant Garde Goddess}

Artemis of Ephesos may or may not have many "breasts," a debatable point, but she certainly has two faces, or more properly, two bodies in both iconography and literature. ${ }^{1}$ One body is that of the traditional virgin goddess, the huntress of myth, as found in other Greek poleis. The other body, despite the sweet virginal face resembling that of her outdoor namesake, seems to belong to an ancient Anatolian goddess. In one form Artemis skirts over the mountains in a light tunic; in the other she stands rigidly imprisoned in a ponderously embroidered type of straightjacket, the "ependytes". 'She seems to struggle to lift her arms, heavily weighed down by what the Fathers of the Church identified as breasts, and unable to take a step. Whatever the body language involved, both forms apparently belonged to the same person, at least in the late Hellenistic and Roman period.

Naturally, the double nature of Artemis has to do with the Greek presence in the ancient religious sphere of Anatolia. The recent German excavations at Miletos suggest that Greeks were already settled there in the late Bronze Age, much earlier than scholars had previously thought. ${ }^{3}$ Even a vase with a few characters of Linear $A$ inscribed on it has been found, along with the remains of Mycenaean frescoes. The Hellenization of the Anatolian

1 A general treatment of religion at Ephesos can be found in R.E. Oster, Epbesus as a Religious Center under the Principute. I. Paganism before Constantine, in ANRW, II, 18.3 (1990), p. 1662-1728.

2 For Greeks taking different cult forms as manifestations of the same divinity, see C. Sourvinou-INwoOd, Tragedy and Religion: Constructs and Readings, in C. Pelling (ed.), Greek Tragedy and the Historian, Oxford, 1997, p. 161-186, esp. p. 164-170.

3 The excavator, Wolf-Dietrich Niemeier, has presented the evidence in a number of recent lectures and in very brief form as New Excavations in Bronze Age Miletos 1994, in $B I C S, 40$ (1995), p. 260-261. For the Mycenaean presence at Ephesos, see S. Karwiese, Groß ist die Artemis von Ephesos. Die Geschichte einer der großten Städte der Antike, Vienna, 1995, p. 13-18. A. Bammer, U. Muss, Das Artemision von Ephesos. Das Weltwunder Ioniens in arcbäischer und klassiscber Zeit, Mainz, 1996, p. 25-28, think it quite likely there was a Mycenaean cult site under the Artemision, judging by the Mycenaean artifacts (calf, "Lord of Asine" type head, and double ax) found in the immediate vicinity (p. 27). 
goddess and intensive Greek contact with her, then, may go back even farther than once thought.

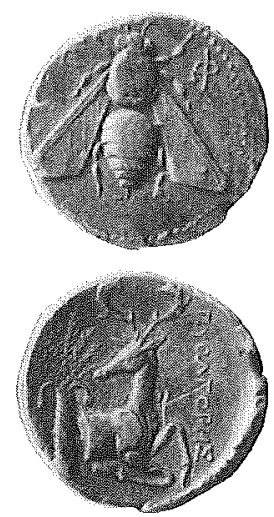

Fig. 1

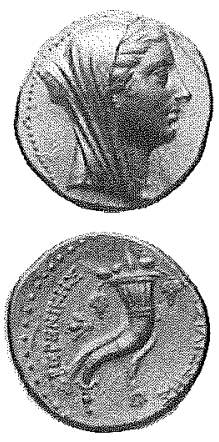

Fig. 2

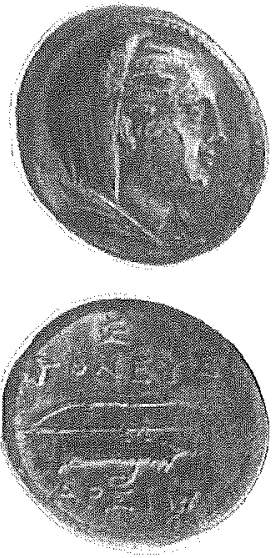

Fig. 3

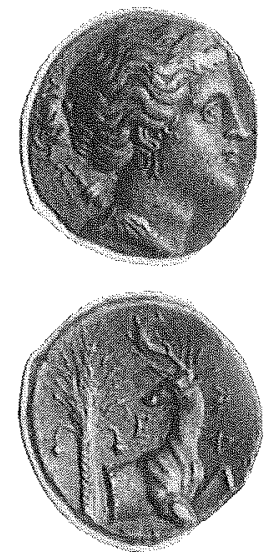

Fig. 4

The tension between the "Greek" and "Ephesia" forms of the goddess continued into the late Empire, though the iconography was constantly changing. Coins tell the story, A beautiful tetradrachm produced just before the Hellenistic period represents a bee on the obverse, a protome deer and palm tree on the reverse, all of which were presumably symbols of the goddess (Fig. 1). The date palm evidently represents the birth of Artemis by the sacred palm (pboinix), thus suggesting her nativity, celebrated in one of her two most important festivals. ${ }^{4}$ The obverse of some of the early Hellenistic coins portrays the head of a monarch or his consort, (such as Demetrios, Berenike II, or Arsinoe - the consort of Lysimachos - with no apparent reference to Artemis on the reverse) (Fig. 2). Of these, the reverse of the Demetrios Poliorketes issue has a standing Poseidon thrusting a trident, his favorite coinage at this time. The dignified portrait of Berenike, if it were not for the veil covering the back of her head, might be mistaken for that of Artemis, but the reverse shows a typically Alexandrian cornucopia. However, the reverse of a similar Arsinoe coin (at a time when Ephesos was called Arsinoe or Arsinoeia after her) portrays the quiver, bow and arrows of Artemis, thus suggesting both the city and an assimilation of Arsinoe to the

4 Strabon, XIV, 1, 20, mentions an olive tree at the Ephesian birth place (of Apollon as well as Artemis); in contrast Kallimachos, Hymn to Delos, 209-210, mentions the palm at Delos. 
goddess (Fig. 3). ${ }^{5}$ The reverse of a similar coin of the same mint and date, however, portrays a different attribute of Artemis, a full stag without palm (no. 258). By the end of the third century, the head of Artemis has replaced the bee on the obverse of the type consisting of bee/stag protome with palm; but a similar reverse (stag protome with palm) remains (Fig. 4).

Cistophoric coins (snakes around a cista mystica) appear between 160150 B.C., while Ephesos still belonged to the Kingdom of Pergamon (Fig. 5). The symbol at first sight suggests that the coin was adapted for Artemis and that mysteries had been associated with her cult, but it belongs to Dionysiac iconography and was a popular coin type. In fact, the Pergamene kingdom issued this type of coin for sixteen different cities in their kingdom, with the city name indicated on the reverse. ${ }^{6}$ On the Ephesos coin - dated to 175-166 B.C. - a tiny Artemis Ephesia peeks out timidly from behind a huge snake encircling a quiver (Figs. 5-6) ${ }^{7}$ Apparently this represents the shy debut of the Ephesia, at least on coins.

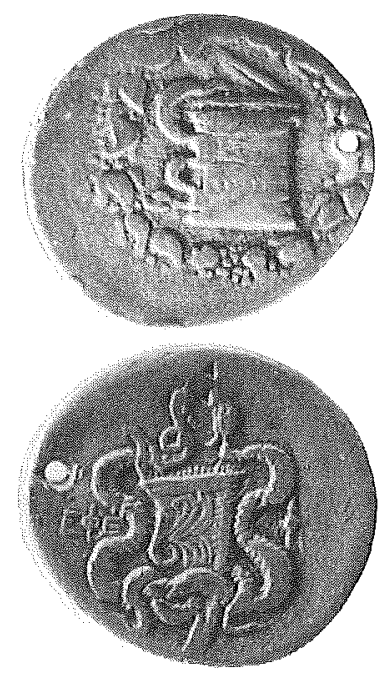

Fig. 5.

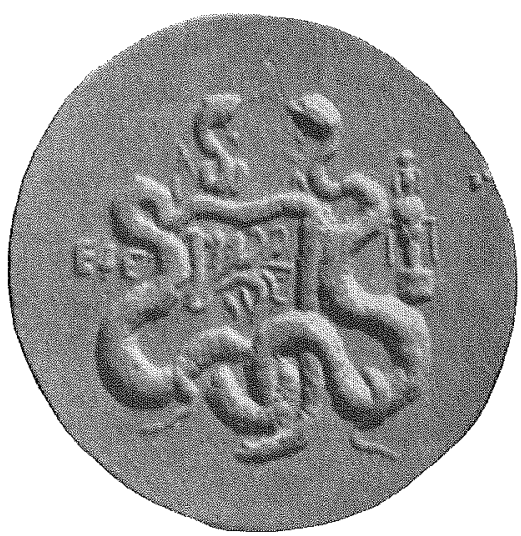

Fig. 6.

5 For Arsinoe and the coin, see KARwiese, op. cit. (n. 3), p. 65-66, pl. 27-28; for the Hellenistic city, C. 294 B.C., see G.M. COHEN, The Hellenistic Settlements in Europe, the Islands, and Asia Minor, Berkeley, 1995, p. 177-180.

6 R. Fleischer, art. Artemis Ephesia, in LIMC, II (1989), 1, p. 754-763; 2, p. $564-573$ (1, p. $758 ; 2$, p. 565 , pls. $22-23$ [22 dated to $159-133$ B.C.I). KArwiese, op. cit. (n. 3), p. 70, thinks a taboo against representing the cult image had disappeared at this time.

7 Fleischer, art. cit. (n. 6), 1, p. 758, no. 22 and 2, p. 565, no. 22; R. FleIscher, Artemis von Ephesos und verwandte Kultstatuen aus Anatolien und Syrien, Leiden, 1973 (EPRO, 35), p. 438, pl. $51 \mathrm{~b}$ (dated to 159-133 B.C.); see also $52 \mathrm{a}$ and 52b. For a revision of the dating see G.K. Jenkins, Hellenistic Gold Coins of Ephesos, in C. Bayburtuuoglu (ed.), Festschrift Akurgal, Ankara, 1987, p. 183-188 [= Anadolu (Anatolia), 21 (1978-1980)]. 
Not until 126/125 B.C. in Mørkholm's analysis, does the first, crude image of Artemis Ephesia appear alone. Her numismatic debut as a soloist, however, came on the reverse of a coin which schizophrenically retained the earlier "Greek Artemis" on the obverse, though now looking a bit aged, puffy, and matronly (Fig, 7), ${ }^{8}$ Jenkins left two possibilities open, either that the coin type began in the year "one" (134/133 B.C.), thus starting with Roman rule, or that it had already been minted in the Attalid period. ${ }^{9}$ Beginning in the second century, but especially during the Roman period, the Ephesia type came to predominate in iconography. It had the advantage of offering a remarkably distinctive image to the Ephesian goddess, much like that of the famous Tyche of Antioch. The Greek form was never excluded, and writers of romance even pretended that the Ephesia did not exist. ${ }^{10}$ Evidently, then, until around 150 B.C., the city tried determinedly to project a primarily Greek image of their goddess to the outside world, just as the novelists did in the Imperial period. Did something happen to cause the change around this time?
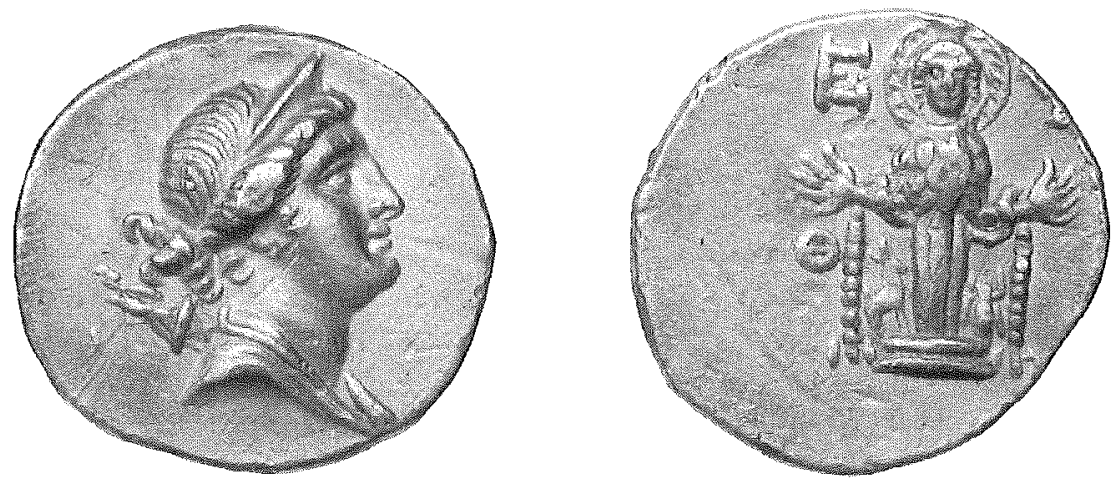

Fig. 7.

8 References to the coins mentioned above are to O. Mørkholm, P. Grearson and U. Westermark, Early Hellenistic Coinage. From the Accession of Alexander to the Peace of Apamea (336-188 B.C.), Cambridge, 1991, nos. 169, 255, 256 (similar, 566), 313, 570, 617, 657 (a type datable in one instance to 120 B.C.); KARwIESE, op. cit. (n. 3), p. 71, pl. 34, along with other coins, pls. 16-17, 27-38 (descriptions, p. 66-78).

9 Jenkins, op. cit. (n. 7), p. 186; see pls. A.1 and 2; G.K. Jenkins, M. Castro Hipólito, $A$ Catalogue of the Calouste Gulbenkian Collection of Greek Coins, II, Lisbon, 1989, text p. 136-137, pls. XC and XCI, and nos. 984-986.

10 See C.M. Thomas, At Home in the City of Artemis. Religion in Ephesos in the Literary Imagination of the Roman Period, in H. KoEster, Epbesos. Metropolis of Asia. An Interdisciplinary Approach to its Archaeology, Religion, and Culture, Valley Forge, 1996, p. 81117 , esp. p. 85-89, 90-93. 
It could be that the rivalry between the two forms of the goddess runs very deep. There may have been two Anatolian types haunting Ephesos; or perhaps one type broke down into two Greek forms, the Artemis Ephesia and the Kybele, or even into three, Artemis, Kybele, and Hekate. Excavations reveal two (or three) ancient cult sites at the Artemision. The different sites complicate the situation there, but they may have nothing to do with two different goddesses or one goddess conceived as two ${ }^{11}$ More important in this respect are other excavations on the northeast slope of Mt. Panayirdag (Pion), the hill to the east of the Hellenistic city. They suggest that this area originally and from time primordial had been dedicated not to the virgin Artemis but to the Great Mother, Kybele. Only later - in the reconstruction of the Austrian archaeologists - did the Artemision Artemis appropriate this area for herself. ${ }^{12}$ Even so, the appropriation seems to be mostly the use of the area for the processional route to the Artemision. Perhaps one could ask a question here. At the time the cemetery area on the east slope first came under the patronage of Kybele, was Kybele already differentiated from Artemis? ${ }^{13}$

At any rate, Ephesos is a city, not all that uncommon in Asia Minor, in which the principal deity, at least in the historical period, belonged to an "extra-mural" or "peri-urban" sanctuary. François de Polignac somewhat revolutionized the concept of poliade religion with his distinctions of "suburban," "peri-urban," and "extra-urban," and by his assertion that the extraurban sanctuary belonged to the city in a manner that made it quintessentially "poliade."14 De Polignac noted that for Homer sacred space was primarily the sacred grove (alsos), and that early "cities" often consisted of groups of disorganized villages or homes, whose focal point and center was not a city or conglomerate but the extra-urban shrine. In his view, this situation was particularly true of the sub-urban or peri-urban shrines of Athena at Delphi, and of Artemis in Sparta, Thessaly, Pheres, Delos, Athens, and Ephesos. Moreover, de Polignac asserted that the primordial poliade shrines usually were not in the city and that in fact a major characteristic of the

11 See Karwiese, op. cit. (n. 3), p. 17.

12 D. Knibbe, G. Langmann, Via Sacra Ephesiaca, I, Vienna, 1993 (Ber. E Mat. ÖAI, 3), p. 9-11; D. KNibBe, H. Thür, Via Sacra Ephesiaca II. Grabungen und Forscbungen 1992 und 1993, Vienna, 1995 (Ber. \& Mat. ÖAI, 6), p. 99; D. KNıBBE, Via Sacra Ephesiaca: New Aspects of the Cult of Artemis Ephesia, in Koester, op. cit. (n. 10), p. 141-157. See also G. Sfameni-Gasparro, Per la storia del culto di Cibele in Occidente: il santuario mipestre di Akrai, in E.N. LANE (ed.), Cybele, Attis and Related Cults, Leiden, 1996 (RGRW, 131), p. 51-86, esp. p. 62-66; M. Aurenhammer, Sculptures of Gods, in Koester, op. cit. (n. 10), p. 251-280, esp. p. 255-260; Hueber, op. cit. (n. 18), p. 32, pl. 40.

13 For the site, see Karwiese, op. cit. (n. 3), p. 26-27.

14 F. DE Polignac, Cults, Territory, and the Origins of the Greek City-State, Chicago, 1995 (= La naissance de la cité grecque. Gultes, espace et société VIII-VII siècles avant J.-C., Paris, 1984), p. 21-25. 
emergence of the polis was the construction of a massive extramural sanctuary to accompany it. He also believed that practically all the great nonurban sanctuaries were built over the remains of the Bronze Age. ${ }^{15}$ He shared the view of others that sanctuaries served to stake out territory, especially when they overlooked agricultural plains. But perhaps more original with de Polignac is his new structuralist conception: the shrines marked off and mediated between the civilized city and the wild nature of the open spaces and mountains; and, in particular, divinities such as Artemis and Apollon, the "limitropes," the gods of the rite de passage, fit well into these limitrophe zones. ${ }^{16}$ This conception, however, has been contested by Malkin and others who see the shrines as independent of the organization of the city. Malkin, for example, sees too much fluidity in the boundaries of the city at its foundation, to support de Polignac's theory. ${ }^{17}$

Some, but not all the elements of de Polignac's description characterize the situation at Ephesos. ${ }^{18} \mathrm{He}$ himself revised some views in the English version of his book through a better awareness of the special nature of shrines like the Heraion at Samos and the Artemision at Ephesos. Even while writing the French version, he was intrigued by the two cult sites at the earlier Artemision. They suggested an openness to the surrounding world and the fusion of the Greek and Lydian populations through intermarriage. ${ }^{19}$ Realizing, moreover, that Ephesos was a poor fit with his model polis, which had been primarily constructed from the situation of mainland Greece, he associated Ephesos more with the colonial structures of the Western Greeks. $^{20}$

15 DE Polignac, op. cit. (n. 14), p. 27-28.

16 DE Polignac, op. cit. (n. 14), p. 20-38, esp. p. 27, 33, 38. Artemis' very non-poliade character contrasts, for example, with Athena's. See K. Clinton, Artemis and the Sacrifice of Ipbigeneia in Aescbylus' Agammnon, in P. Pucci (ed.), Language and the Tragic Hero, Atlanta, 1988, p. 1-24, esp. p. 7.

17 I. MALKin, Territorial Domination and the Greek Sanctuary, in P. Hel.ström, B. Alroth, Religion and Power in the Greek World, Uppsala, 1996 (Boreas, 24), p. 75-82. He prefers the sacrificial model in which the gods "get their share": they too receive territory; but in fact it is "fat," too risky to be very desirable for men (p. 75, 78-79).

18 For the geographical situation at Ephesos, see the maps, for example, in KARwiEsE, op. cit. (n. 3); and F. Hueber et al., Epbesos. Gebaute Gescbichte, Mainz, 1997, p. 30-34, esp. p. 31, pl. 39. In the Ionian phase the Artemision site, on the sea and at the river mouth, was the only level place along the coast.

19 For the two cult places and indigenous populations, see STraBon, XIV, 1, 21; $c f$. KNIBBE, loc. cit. (n. 12), p. 143; A. BAMMER, Les sanctuaires archaïques de l'Artémision d'Éphèse, in R. ÉtIEnne, M.-T. Le Dinahet (eds.), L'espace sacrificiel dans les civilisations mêditerranéennes de l'antiquité, Paris, 1991, p. 128-130.

20 de Polignac, op. cit. (n. 14), p. 75-77. 
De Polignac's original study in French was followed by Malkin's study on religion in the colonies. This offered some challenging new conclusions. ${ }^{21}$ Malkin, for example, believed that the founders of colonies, in their desire to create an extramural sanctuary, for the most part were not influenced by the inherent sacredness of the place or indication of an indigenous cult there. Rather, they were guided by their own consideration of what territorial organization should be like. In his treatment of these sacred places, which might include summits, caves, springs, or groves, he found no precise, explicit references in Greek authors for the continuation of a non-Greek cult in a local sacred area. But he saw such continuity as a distinct possibility. Since Greek writers frequently mention honor paid to local heroes, it would have been reasonable for early Greeks to respect local religious precedent. ${ }^{22}$ Nonetheless, he found the theory of "native cult sites" considerably weakened by the latest archaeological data. He concluded that in general the theory of building over an indigenous cult should be excluded from discussions of central and suburban (not necessarily extra-urban) sanctuaries. ${ }^{23}$ Should the Artemision be called extra-urban? Some authors require five kilometers distance from the city for an extra-urban sanctuary, whereas the Artemision is, at best, about two and a half kilometers from an ancient wall of Ephesos, and as the crow flies only one and a half. ${ }^{24}$ Originally the temple, which was in a strategic position next to the sea (harbor) and overlooking a plain to the east, south, and west, might have prevented others from settling there. De Polignac sees as very significant Kroisos' (Croesus') reordering of the sanctuary. The original two cult sites disappeared under a huge temple and accompanying altar to the west. Moreover, a wall surrounding them considerably limited the space available. ${ }^{25}$

The mediating function of the Artemision deserves investigation. Differences between de Polignac's original book in French and the English

21 I. Malkin, Religion and Colonization in Ancient Greece, Leiden, 1987.

22 Ibid., p. 137, 141-143, 153-154, 175, 183-185.

23 For the city in the 2nd millenium, see Karwiese, op. cit. (n. 3), p. 14. Pausanias, VII, 2, 8, probably following Ephesian revisionism, disputes the tradition, found in Pindar, that Amazons founded the Artemision. Rather, the semi-divine local figures, Koressos and Ephesos, had founded the sanctuary before the Amazons arrived. Androklos, then, the ktistes of Ionian Ephesos, had no role in the original foundation of the sanctuary and in fact had to drive away the local inhabitants; $c f$. KarwiEse, op. cit. (n. 3), p. 25-26; Bammer, Muss, op. cit. (n. 3), p. 29-32. - For the cult sites in the 8th cent., see W. Alzinger, Ephesiaca II. Ergänzungen und Korrekturen nach neuesten Funden und wenig beacbieten Literaturstellen, in G. DoBESCH, G. REHRENBÖck, Hundert Jabre Kleinasiatische Kommis. sion der Österreichischen Akademie der Wissenschaften, Vienna, 1993 (Ergzbd. Tituli Asiae Minoris 14. OAW. Pbilos.-Hist. Kl. Denkschriften 236), p. 49-58, esp. p. 54, fig. 4 b. Alzinger believes that the altar of "Protothronia" to the west of the Hellenistic temple was not for Artemis, but for another divinity.

24 See Karwiese, op. cit. (n. 14), map 1.

25 DE POLIGNaC, op. cit. (n. 14), p. 76, 81 
version, particularly over the nature of the rural or extra-urban sanctuaries, came out sharply later in a contribution to a volume on Greek sanctuaries. The article, published a year before the English translation of the book, consists of "pentimenti," changes and additions to be incorporated in the forthcoming English version. ${ }^{26}$ De Polignac retained the idea that sanctuaries represented territorial claims, but extended their function to include influence over vast areas. For example, he saw a strict correlation between the construction of the Heraion at Samos and the expansion of Greek trade on the Aegean. As a consequence of this trade, the Heraion opened itself up to foreign influence and religious practices. The rise of such a huge sanctuary at Samos and elsewhere in the ninth, then, was concomitant with the enormous expansion not only of Greek trading activity, but perhaps piracy, as the Greeks regained their initiative on the sea, and acquired new wealth. ${ }^{27}$ Because many offerings came from afar, the temple offered a mediating role between the city and the rest of the world, particularly the world stretching to the east. De Polignac felt that in a similar way, the Artemision, which was frequented by Phoenicians at an early date, would be a port-of-call. ${ }^{28}$ The port-of-call patroness was the virgin Artemis.

Shortly after the appearance of de Polignac's "pentimenti", Catherine Morgan underscored the mediating role of Greek sanctuaries among indigenous populations. In her view, the Ionian Greeks, threatened by powerful monarchs surrounding them, lived in a precarious situation. They were a minority in an alien world. Alien elements existed as well within their own population, often through intermarriage. The Ionians, then, needed to find an acceptable, non-threatening means of expressing their cultural identity within the Greek community, while at the same time offering something to the world around. They resolved the dilemma through the paradoxical creation of a state sanctuary which was in effect a huge extra-urban temple. The Greek divinity remained supreme but was related, formally or informally, to a foreign cult. The relationship between the Greek Artemis and the Anatolian "Great Goddess" would be a case in point. ${ }^{29}$

26 F. DE Pol.ignac, Mediation, Competition, and Sovereignty: The Evolution of Rural Sanctuaries, in S.E. Alcock, R. Osborne (eds.), Placing the Gods. Sanctuaries and Sacred Space in Ancient Greece, Oxford, 1994, p. 3-18. See also his Influence extérieure ou évolution interne? L'innovation cultuelle en Grèce géométrique et archaique, in G. KOPCKE, I. Tokumaru (eds.), Greece between East and West: 10th-8th Centuries BC, Mainz, 1992, p. 114-127, esp. p. 124-125, with map, fig. 14, of the archaic Artemision site.

27 See C. Morgan, The Origin of Pan-Hellenism, in N. Marinatos, R. Hägg (eds.), Greek Sanctuaries. New Approaches, London and New York, 1993, p. 18-44.

28 De Polignac, op. cit. (n. 14), p. 6-7. Some of his conclusions have been challenged or modified by C. Sourvinou-Inwood, Early Sanctuaries, the Eighth Century and Ritual Space. Fragments of a Discourse, in Marinatos, HägG, op. cit. (n. 27), p. 1-17.

29 Morgan, loc. cit. (n. 27), p. 33-34. 
If Morgan is right, the Lydian king, Kroisos, might not have viewed the Artemision primarily as a Greek sanctuary and himself as a generous foreign benefactor. Rather, he might have seen the Artemision as a Greek architectural expression of devotion to the Anatolian goddess, the patroness worshipped in Asia Minor from time immemorial. ${ }^{30}$ The "cosmopolitan" nature of the shrine would have been emphasized by a display of exotic offerings from the neighboring populations, as well as those from far off Phoenicia and Egypt. ${ }^{31}$ For example Kyrieleis describes the Heraion at Samos as an open-air museum of Greek and exotic art, consisting of votive offerings and gifts from distant Egypt, Syria, and Babylon. Small bronze figurines of a man and a dog seem strangely out of place, but they belong to the Babylonian cult of the goddess Gula, who in Kyrieleis' view might have been identified with the Samian Hera. ${ }^{32}$ The circumstances at the Artemision undoubtedly were similar.

The mediating role of the Artemision probably affected the statue type. Before the second, or Kroisos temple, was built, the cult statue of Artemis may not have been "oriental." If it changed at this time to something like the "Ephesia," the decision might have been influenced by the need to accommodate the religious sentiments of the indigenous population, while finding an acceptable compromise with Greek devotion. It is also possible that Kroisos would have been pleased with a less Greek image. But the Ephesians might have been determined to retain their cultural identity and their link with the rest of the Greek world by representing the cult statue in a completely Hellenic fashion. ${ }^{33}$ Looking only at the numismatic evidence, one would deduce that until the mid-second century B.C., the cult statue was purely Greek. Moreover, Strabon seems to suggest there were several "cult statue" types. $^{34}$ Some may have resembled the "Rhodian" statuettes found in the Malophoros sanctuary at Selinous in Magna Graecia, though the type was

30 Similar is the position of KNiBbe, New Aspects..., cit. (n. 12), p. 143, and Bammer, Muss, op. cit. (n. 3), p. 42-44.

31 For the objects found in the Artemision sanctuary, see G. Hölbl, Archaiscbe Aegyptiaca aus Ephesos. Vorläufige Beobacbtungen zu den Neufunden aus dem Artemision, in Dobesch, Rehrenböck, op. cit. (n. 23), p. 227-264; Morgan, loc. cit. (n. 27), p. 33-34.

32 H. Kyrieleis, The Heraion at Samos, in Marinatos, Hägg, op. cit. (n. 27), p. 125-153, esp. p. 146.

33 See L.T. Lidonnici, The Images of Artemis Ephesia and Greco-Roman Worsbip: $A$ Reconsideration, in $H T b R, 85$ (1992), p. 389-415, esp. p. 398-401 and pl. 7. The name Endoios is a restoration in a corrupt text (PLINY, N.H., XVI, 79, 213-216). For the Rhodian, "Malophoros" type, see M. Dewailly, Les statuettes aux parures du sanctuaire de la Malaphoros à Sélinonte, Naples, 1992 (Cabiers Centre Jean Bérard), esp. p. 48-49, fig. 13-14; 79, fig. 43 (high slung type); fig. 43; 104-105, fig. 64-65 and 110-116, fig. 70-79 (low slung type) (see plate). See also V. Jarosch, Samiscbe Tonfiguren des 10. bis 7. Jabrbunderts $v$. Cbr. aus dem Heraion von Samos, Bonn, 1994, p. 133, 148; pl. 36, no. 512; pl. 40-41, no. 715, 718.

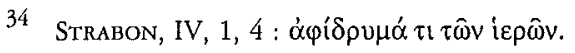


widely diffused throughout the Greek world. In some respects, either with higher or lower slung "breasts," they bear a striking resemblance to the Ephesia (Fig. 8-9). The famous "breasts" of the Ephesia, then, suddenly seem

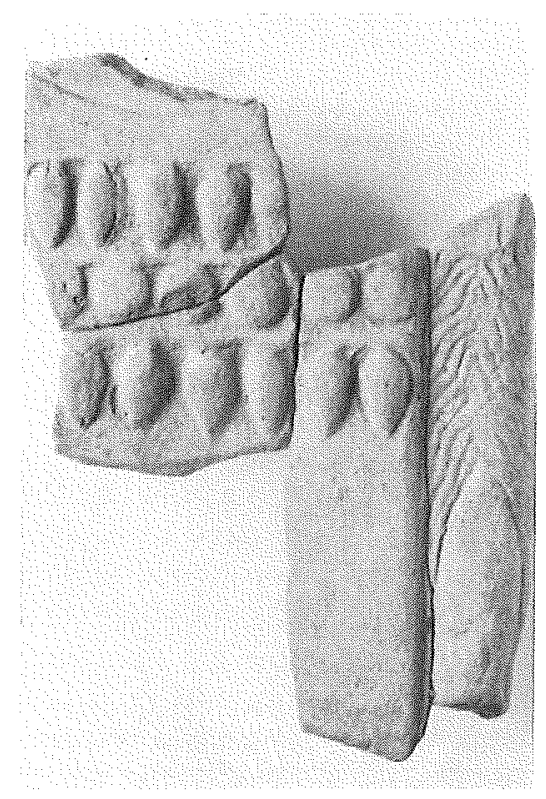

Fig. 8.

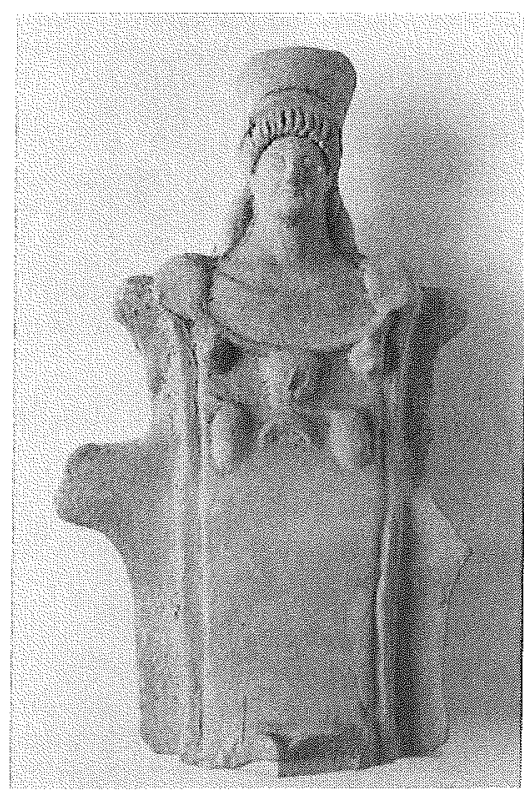

Fig. 9.

to vanish into flamboyant, somewhat overly optimistic, and luxurious "parures" (ornaments), the adornment typical of other Asiatic divinities. ${ }^{35}$ Here, too, one depicts the cross-influences of religious worlds with fluid boundaries. Correspondingly, with Kroisos and the Persians only a memory, after their liberation by Alexander, the Ephesians may have wanted to present a purely Greek Artemis to the outside world. If the Kroisos statue or the sanctuary had Anatolian traits, they may have felt themselves constrained earlier into making this rapprochement. A vaunting of the Greek form suggests the reappropriation of the Artemision for a more Hellenic goddess and a return to the situation before Kroisos. An "Oriental" form might have suggested the previous integration of Ephesos into the vast territory of Lydian

35 G. Zuntz, Persephone, Oxford, 1971, p. 128-130, 139-141, pls. 15-18, identified this relationship years ago. For familiar shapes, see Y. TABorin, La parure en coquillage au paléolitique, Paris 1993, esp. p. 185, fig. 61, and M. Szabó, Archaic Terracottas of Boeotia, Rome 1994, fig. 24, 59 (seated "pappas"), 61, 95, 104, 115, esp. 136 (7th Cent.) (Fig. 10). See also I. Bald Romano, Early Greek Cult Images and Cult Practices, in R. Ḧ̈GG, N. Marinatos, G.C. Nordquist (eds.), Early Greek Cult Practice, Stockholm, 1988, p. 127133, esp. p. 129, 132. 
and Persian Asia Minor. ${ }^{36}$ Possibly, then, the new statue carved for the Hellenistic temple was more "Greek" than the Kroisos one. Strabon mentions other Hellenistic statues created to adorn the Artemision this time, among which were those of Praxiteles, a "Greek" sculptor par excellence.

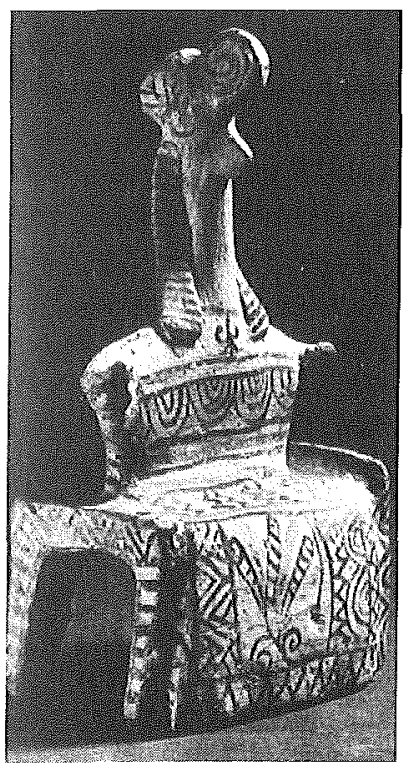

Fig. 10.

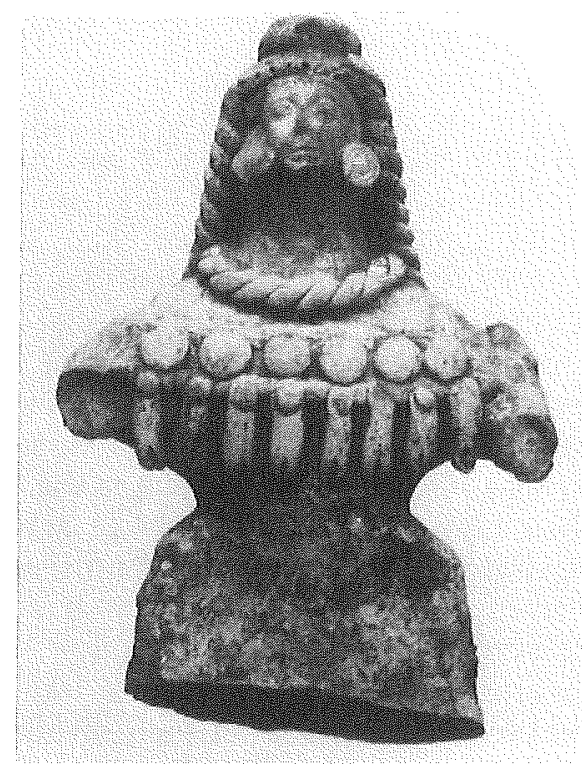

Fig. 11 .

Morgan explained the creation of such expensive and massive extra-mural sanctuaries as a means of keeping out foreigners, and thus avoiding a security problem. ${ }^{37}$ With the Artemision the physical safety and the Hellenic identity of the Ephesians could be better assured. ${ }^{38}$ Perhaps Morgan's idea can be carried one step further. When Kroisos constructed his city of Ephesos around the sanctuary - without particular concern for Greek sensibilities - he may have welcomed the possibility of breaking down the isolation of the formerly independent Greek city and better integrating its citizens into his realm. He might have even welcomed a "security problem". ${ }^{39}$

36 For some of the syncretism there and changes, see J.O. SMITH, The High Priests of the Temple of Artemis at Ephesus, in LANE, op. cit. (n. 12), p. 323-335.

37 C. Sourvinou-Inwood, What is Polis Religion?, in O. Murrax, S. Price, The Greek City, From Homer to Alexander; Oxford, 1990, p. 295-322, notes the tendency to exclude foreigners from poliade cults (p. 295-296, 300).

38 Morgan, loc. cit. (n. 27), p. 33-34.

39 Karwiese, op. cit. (n. 3), p. 33, and BAMmer, Muss, op. cit. (n. 3), p. 42-44, also seem to be of this opinion. 
When the change to the Ephesia coin type occurred much later - and this was as much a remodeling as a replacement - the political situation had drastically changed. The Greeks of Ephesos were no longer a small ethnic island in a barbarian sea. Like their neighbors, they had been part of Hellenistic kingdoms for generations, with their security guaranteed by the relative strength of the contemporary monarch. They were, then, less threatened by progressively more Hellenized neighbors. In fact, the numismatic change occurs - if Jenkins is right - around the time the Attalids ceded their territory to the Romans and the Ephesians were incorporated into the Province of Asia. Both politically and culturally, after years of the Hellenization of western Asia Minor, the Ephesians would have felt relatively secure in their Greek identity. But now they were Graeco-Romans. The city had long been a kind of regional capital, even though inferior in this respect to Alexandria, Antioch, or Pergamon. When, under Augustus, Ephesos officially became the capital of the province, the city rose to the challenge. It became not only the political capital, but also in a sense the religious capital of western Asia Minor. A reflection of this religious status appears in the incorporation of the various foreign gods of Asia into the "Temple of Domitian" or "Sebastoi," and their representation on the late antique frieze of the so-called Temple of Hadrian. ${ }^{40}$ With its many representations of exotic, Asian divinities, the statues and the frieze seem to shout out "All the gods of Asia support the Emperor and the Flavian dynasty." 41 But it can also suggest the Emperor's incorporation, in a paternalistic way, not only of all the inhabitants of Asia into his cult, but also of their divinities. They might be happy to learn that their god had not been slighted.

Does the palm tree on the early coins of Ephesos also tell a tale? While most of the religious history of the city is lost to us, the Ephesians, evidently at an early stage, linked the Greek Artemis with the goddess - or one of the goddesses - who held sway over Anatolia. The Ionians would have brought their own Artemis with them. Moreover, they entered a part of Asia Minor that had been occupied by an Indo-European group. ${ }^{42}$ Did they try to Hellenize the Anatolian goddess right from the beginning, relating the local divinity to Zeus, Apollon, and Leto? Even if the Artemision did not belong to an ancient cult site, the presence of the Anatolian goddess in the region must

40 For the dating see Karwiese, op. cit. (n. 3), p. 125-126. Artemis Ephesia is strangely absent.

41 S.J. FRIESEN, Twice Neokoros. Ephesus, Asia and the Cult of the Flavian Imperial Family, Leiden, 1993 ( $R G R W, 116)$, p. 74-75; and The Cult of the Roman Emperors in Ephesos. Temple Wardens, City Titles, and the Interpretation of the Revelation of Jobn, in KoEster, op. cit. (n. 10), p. 229-250, esp. p. 232.

42 For the historical period, see G. PETzL, Ländlicbe Religiosität in Lydien, in E. Schwertheim (ed.), Forscbungen in Lydien, Bonn, 1995 (Asia Minor Studien, 17), p. 3748, esp. p. 37-38. In both the Anatolian and Persian religious strata, the leading female divinity is a mother goddess, and in the Anatolian, she is the best attested divinity as well. 
have been known and felt. At a later period, Greeks or the indigenous peoples themselves certainly tried to Hellenize the local gods, and often succeeded. But sometimes it worked both ways. Though poliade gods like Zeus, Athena, Apollon, Aphrodite, Dionysos, and Asklepios are attested for Ephesos, in some instances they, too, seem to have uncharacteristic, Anatolian traits. ${ }^{43}$ Most of our evidence for religion at Ephesos is very fragmentary and late. Nonetheless, while the city shrine of Artemis near the beach may have been the abode of a thoroughly Greek poliade goddess, the Artemision - "seven stades distant" - retained major links with the Anatolian past.

In the Ephesian cult, Artemis was not born at Delos but at a place near the city called Ortygia ("partridge"). ${ }^{44}$. The palm was very important in the Delian cult of Apollon for designating his birthplace. Presumably the stag with palm obverse on Ephesian coins indicates the birth of Artemis under the pboinix (palm) at Ortygia. The palm seems to be unrelated to the Ephesia iconography. However, apparently beginning in the Roman period, the stag, or rather a pair of stags, was incorporated into some of her statues, possibly even into the cult statue. ${ }^{45}$ The addition suggests an attempt at greater Hellenization and Romanization by making her more recognizably the Artemis that Greeks and Romans knew and loved. ${ }^{46}$ Perhaps, too, the lines separating the iconography for different cults were becoming blurred at Ephesos. Significantly, perhaps, the festival at Ortygia, the alleged birthplace of Artemis and Apollon, was not in the immediate vicinity of the Artemision. Because the Nativity was one of the most important festivals of the goddess, it inevitably drew to itself the cult at the Artemision. Still, the birth of the Greek Artemis represents a different complex of religious ideas than those surrounding her mysterious looking Anatolian double.

The latter apparently had no mother, father, nor brother; at best, in her Kybele form, she is trailed by a castrated boy or youth. The Anatolian goddess remains supreme, aloof, unsubordinated. The Ionians, however, may have attempted to find her a husband. Dedications to Zeus Patroios have been found in the area dedicated to Kybele, at the east end of the Hellenistic

43 See D. Knibre, Ephesos - nicht nur die Stadt der Artemis. Die 'anderen' ephesiscben Götter, in S. SAHIN et al. (eds.), Studien zur Religion und Kultur Kleinasiens, II, Leiden, 1978 (EPRO, 66), p. 489-503, esp. p. 491; Aurenhammer, loc. cit. (n. 12), p. 251-280.

44 See Karwiese, op. cit. (n. 3), p. 79, 85, 111. The festival itself, according to STraboN, XIV, 1, 20, describes the place and rite. See also P. Trebilico, Asia, in D.W.J. Gill, C. GEMPF (eds.), The Book of Acts in Its Graeco-Roman Setting, Grand Rapids, Michigan, 1994, p. 291-362, esp. p. 321-322; Thomas, loc. cit. (n. 10), p. 89; KNIBBe, New Aspects..., cit. (n. 12), p. 144, 148-149.

45 See Fleischer, op. cit. (n. 7), p. 112-114.

46 Similar coins in Fleischer, op. cit. (n. 7), p. 439, pl. 53b (87-84 B.C.) and 53c (probably Artemis Ephesia, 66 B.C., Gortyn) show the cult statue with cornucopia and bee. 
city. ${ }^{47}$ Kybele herself is called Patroie. ${ }^{48}$ Evidently the Anatolian Kybele had Zeus as a paredros or, what is more likely, the Ionians subjugated her, by forcibly bedding her with Zeus.

In conclusion, the image of the Ephesian Artemis parallels the religious history of the city. The official image presented to the outside world in coins was, until the mid-second century B.C., the Greek type. Even the cult statue in the Archaic period may have been a highly diffused Ionian "Malophoros" type used for several goddesses throughout the Greek world, that is, of a female divinity with Oriental polos, modest ependytes, and "parures." As attested in Greek literature, the sculptor of the cult statue created for the Kroisos temple was a "mainlander" whose major activity had been in Attica. Several kinds of "cult statue" may have existed. The change to the Ephesia in the official imagery of the city possibly represents a sense of greater religious security, along with an effort to make the goddess more distinctively recognizable, representative, and appealing to the region of Anatolia, and then to the whole world. Perhaps they overdid it. The change would probably involve the growing importance of Ephesos as a regional center under the Attalids in the second century, then under Roman rule, in particular, as the capital of the province of Asia, and finally as one of the wonders of the world and a universal shrine. ${ }^{49}$ The paradox, however, remains. Artemis Ephesia, the very symbol of a thoroughly Hellenistic city, its poliade goddess par excellence, remains unnervingly alien, strange, and Anatolian. ${ }^{50}$

Frederick E. BRENK

Pontifical Biblical Institute

Via della Pilotta 25

I - 00187 ROME

47 For the area, see KNiBbe, New Aspects..., cit. (n. 12), p. 142-143, and map (155).

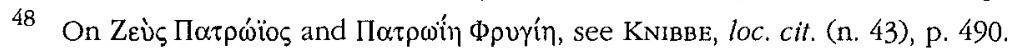

49 For more specific details, see, for example, KARwIESE, op. cit. (n. 3), p. 71, 179.

50 Thanks are due to Leu Numismatik, Zürich, Fundação Calouste Gulbenkian, Lisbon, The Royal Collection of Coins and Medals, National Museum, Denmark, The British Museum, London, Royal Coin Cabinet, National Museum of Monetary History, Stockholm, E.J. Brill, Leiden, "L'Erma" di Bretschneider, Rome, and the Cambridge University Press, Cambridge, for permission to use the illustrations or material from their collections or books. The Gulbenkian Foundation made a gift of the necessary photographs.

I would also like to thank Professor Robert Parker of New College, Oxford, for kindly going over an early draft of the article. He remains rather sceptical about reconstructing functions for sanctuaries for which no textual evidence exists. Thanks are also due to Mary Hopkins for her usual common sense in making the author's style less enigmatic. 


\section{Figures}

Fig. 1: Ephesos, c. 380-336/334. Tetradrachm (reduced Chian), AR 14.98g Stockholm (SNG, Gustaf VI Adolf 90) [Møвкноцм, op. cit. (n. 8), fig. 255].

Fig. 2: Ephesos, with head of Berenike II. Octodrachm, AV 27.80g Bank Leu 20 (25.iv.1978), 175. Ptolemaios III (246-222) [O. Мфккноцм, op. cit. (n. 8), fig. 313].

Fig. 3: Arsinoe, c. 289/8-280. Octobol (Attic), AR 5.32g. London (BMC, Ionia, 55.71, pl. 10.5) [MøRкноLм, op. cit. (n. 8), fig. 257].

Fig. 4: Ephesos, c. 250-200. Rhodian trihemidrachm (?), AR 4.87g. London (BMC, Ionia, 57.77, pl. 10.8) [Мøвкногм, op. cit. (n. 8), fig. 566].

Fig, 5: Ephesos, c. 160-150. Cistophoric tetradrachm, AR 11.70g. Stockholm. Kleiner and Noe 1977, series 13, no. 12-a [MøккноLм, op. cit. (n. 8), fig. 617].

Fig. 6: Cistophor with Artemis Ephesia (159-133 B.C.) [Fleischer, op. cit. (n. 7), fig. 51b].

Fig. 7: Ephesos, dated year $9(=126 / 5)$. Obv . head of Artemis; rev. cult image of Artemis Ephesia. Stater, AV 8.30g. Lisbon (Gulbenkian II.987). For the date see Jenkins, $o p$. cit. (n. 7), p. 185 [MфокноLм, op. cit. (n. 8), fig. 657].

Fig. 8: Type A1 (SM Pal T2621) [Dewailly, op. cit. (n. 33), fig. 13 ].

Fig. 9: Type BIX a1 (N.I. 13) [Dewallly, op. cit. (n. 33), fig. 70].

Fig. 10: Seated Boiotian "pappas": H. 7 cm. Munich, Staatliche Antikensammlungen 5601 [SzABó, op. cit. (n. 35), fig. 59].

Fig. 11: Fragment of seated Argive female figurine (terracotta) from Argos: H. $11,6 \mathrm{~cm}$. Argos Museum C.22424x [Szabó, op. cit. (n. 35), fig. 136]. 